\title{
MULTINATIONAL ENTERPRISES AND SELECTIVITY CRITERION IN STATE AID CASES
}

DOI: https://doi.org/10.33717/deuhfd.899950

\author{
Arş. Gör. Nihal ÖZKARDEŞ ${ }^{*, * *}$
}

\begin{abstract}
Decisions of the European Union Commission regarding taxation agreements between competent tax authorities and multinational enterprises have been widely discussed. Within this discussion, implementation of the selectivity criterion and specifically the arm's length principle, which is accepted by the Commission as a necessity in the application of state aid rules, has received a lot of criticism. This study will focus on the assessments on selectivity criterion in the decisions regarding multinational enterprises. Within this perspective, the first section will elaborate on the application of the selectivity criterion in cases concerning taxation practices of multinational enterprises. The second section will question the application of presumption of selectivity in case of advanced pricing agreements. The third section will discuss whether multinational enterprises and standalones are in a comparable legal and factual situation. The fourth section will question the legal basis put forward by the Commission to implement arm's length principle.
\end{abstract}

\section{Keywords}

Arm's length principle, Multinational enterprises, State aid, Selectivity, Advanced pricing agreements

Bahçeşehir Üniversitesi Hukuk Fakültesi, İdare Hukuku Anabilim Dalı (e-posta: nihal.ozkardes@law.bau.edu.tr) ORCID: https://orcid.org/0000-0003-1710-1521 (Makalenin Geliş Tarihi: 18.09.2020) (Makale Gönderilme Tarihi: 18.09.2020/Makale Kabul Tarihi: 21.11.2020)

** I would like to thank Asst. Prof. Zeynep Ayata and Assoc. Prof. Ahmet Yayla for their helpful comments. 


\section{DEVLET TEŞVIKKLERİ SORUŞTURMALARINDA ÇOK ULUSLU ŞİRKETLER VE SEÇICILIK KRITERİ}

\section{$\ddot{O} z$}

Yetkili vergi otoriteleri ile çok uluslu şirketler arasındaki vergi anlaşmalarına dair Avrupa Birliği Komisyonu kararları oldukça fazla tartışılmıştır. Bu tartışmalar çerçevesinde, seçicilik kriteri ve özellikle Komisyon'un devlet teşvikleri kurallarının uygulanması için gereklilik olarak gördü̈̆̈̈ emsallere uygunluk ilkesi çok sayıda eleştiriye tabi tutulmuştur. Bu çalışma, çok uluslu şirketlere dair hükmedilen kararlarda seçicilik kriterinin nasıl ele alındı̆̆ üzerine yoğunlaşacaktır. Bu kapsamda ilk bölümde, çok uluslu şirketlerin vergi uygulamalarını konu edinen kararlarda seçicilik ilkesinin nasıl uygulandiğı ele alınacaktır. İkinci bölümde peşin fiyat anlaşmalarının varlı̆̆ında uygulanan seçicilik karinesi üzerine tartışllacaktır. Üçüncü bölümde, çok uluslu şirketler ile bağımsız şirketlerin hukuki ve fiili olarak karşılaştırılabilir olup olmadıkları sorgulanacaktır. Dördüncü bölümde ise, Komisyon'un emsallere uygunluk ilkesini uygulamak için öne sürdüğü hukuki dayanakların geçerliliği sorgulanacaktır.

\section{Anahtar Kelimeler}

Emsallere uygunluk ilkesi, Çok uluslu şirketler, Devlet teşviki, Seçicilik, Peşin fiyat anlaşmaları 


\section{INTRODUCTION}

Multinational enterprises ("MNEs"), benefitting from having entities in a number of states, may allocate their profits throughout these states to optimize their interest. They may also allocate most of their profits in lowtax states to pay less tax. ${ }^{1}$ One way of minimizing the liable global tax for these corporations is to arrange transfer prices -prices remunerated from one group company to another when selling goods-. Such behavior is qualified as "aggressive tax planning". According to the European Union Commission ("Commission"), aggressive tax planning "result [s] in a loss of tax revenue in the Member State where economic value is generated but not taxed, and in Europe as a whole because the tax eventually paid is less than it would have been if the profits had not been shifted."2

Recently, the Commission concentrated to scrutinize advanced pricing agreements ("APAs") between MNEs and tax authorities. APAs are agreements which serve to calculate the taxable profit of an MNE through a method of estimation of the transfer prices at a given future time. The Commission has been looking at whether APAs are in concomitant with a principle called "arm's length principle". This principle suggests to treat the subsidiary of an MNE as a standalone and to estimate the taxable profit of that subsidiary as if the intra-group transactions were realized in an open market. $^{3}$

Originally endorsed in article 9 of The Organization for Economic Cooperation and Development ("OECD") Model Tax Convention on Income and on Capital ("OECD Model Tax Convention") ${ }^{4}$, the primary aim of this

1 Nicolaides, Phedon: "State Aid and Tax Rulings", European State Aid Law Quarterly, 15, 3, 2016, p.416 <https://www.jstor.org/stable/26694075?seq=1\#metadata_info_tab_ contents $>$ accessed 17 April 2020

2 European Commission, 'Commission Staff Working Document Accompanying the document Report from The Commission to the European Parliament, The Council, The European Economic and Social Committee and The Committee of the Regions Report on Competition Policy 2018' (2019) p.68 <https://ec.europa.eu/competition/ publications/annual_report/2018/part2_en.pdf> accessed 3 March 2020

ibid. p.16

This principle is explained in detail in OECD, 'OECD Transfer Pricing Guidelines for Multinational Enterprises and Tax Administrations 2017'(2017) OECD Publishing $<$ https://read.oecd-ilibrary.org/taxation/oecd-transfer-pricing-guidelines-formultinational-enterprises-and-tax-administrations-2017_tpg-2017-en\#page5> accessed 14 April 2020 
principle is to preclude double taxation. ${ }^{5}$ The Commission has established that the arm's length principle is a necessity in terms of Article 107 of the Treaty on the Functioning of the European Union ("TFEU"). In light of this principle, the Commission recognized MNEs to be in a legally and factually comparable status with standalones and examined whether they benefit from lesser tax liability compared to standalones. Accordingly, the Commission is of the view that the transactions between subsidiaries of MNEs should be taxed as if they are standalone firms in order to avoid state aid liability. Since the Commission believes that MNEs and standalones are comparable, APAs endorsing aggressive tax planning are evaluated as selective advantages granted to MNEs.

However, these decisions have been questioned in many different ways. $^{7}$ In addition, U.S. Treasury Department published a White Paper criticizing these decisions. ${ }^{8}$ Among the critiques, one significant issue is whether MNEs and standalones are in a comparable legal and factual status and whether arm's length principle is suitable for the purposes of article 107

$5 \quad$ ibid. p. 15

$6 \quad$ Fiat/Luxembourg (Case 7152) Commission Decision SA.38375 (2014/C ex 2014/NN) [2015] OJ L/351/2016 §228; Apple/Ireland (Case 5605) Commission Decision SA.38373 (2014/C) (ex 2014/NN) (ex 014/CP) [2016] OJ L/187/2017 §249; Starbucks/ Netherlands (Case 7143) Commission Decision SA.38374 (2014/C ex 2014/NN) [2015] OJ L/83/2017 §260-262; Excess Profit exemption in Belgium (Case 9837) Commission Decision SA.37667 (2015/C) (ex 2015/NN) [2015] OJ L/260/2016 §147.

7 See Houthoff: "State Aid and Taxation The European Commission's decisions on tax rulings in the broader State aid perspective", 2019 p.6 <https://www.houthoff.com//media/Houthoff/Docs/Brochure-State-Aid.pdf $>$ accessed 17 April 2020; Petropoulos, Georgios: "State aid and tax rulings: Clarifying the European Commission's approach" $2018<\mathrm{https}$ ://www.bruegel.org/2018/04/state-aid-and-tax-rulings-clarifying-theeuropean-commissions-approach/> accessed 17 April 2020; Gonzalez, Saturnina Moreno: "State aid, tax competition and BEPS: comments on the European Commission's decisions on transfer pricing rulings" University of Leicester School of Law Research Paper, 17, 2017, p.14. <https://poseidon01.ssrn.com/delivery.php?ID= 00712307201309811300312509711812606902907307201408306602708307009208201 30920931070240430420130580380260450750281010060960971020060160230010600 67093064109018093022113023059078090110078127003078024118082065066026019 030115102083076000070070003000025082090\&EXT=pdf $>$ accessed 3 May 2020; Joris, Tony and De Couk, Wout: "Is Belgium and Forum 187 v. Commission a Suitable Legal Source for an EU "At Arm's Length Principle"” European State Aid Law Quarterly, 16, 4, $2017<$ https://www.jstor.org/stable/26694193?seq=1\#metadata_info_ tab_contents $>$ accessed 10 December 2019

8 U.S. Department of the Treasury, The European Commission's Recent State Aid Investigation of Transfer Pricing Rulings (White Paper, 2016) 
of TFEU. Within this scope, in the first section, we will elaborate the Commission's approach on the selectivity criterion concerning the taxation practices of MNEs. In the second section, we will question the Commission's application of presumption of selectivity in case of APAs. In the third section, we will put forward that MNEs and standalones may not be factually and legally comparable. And at last, in the fourth section, we will question the legal basis to apply arm's length principle.

\section{THE APPLICATION OF SELECTIVITY CRITERION IN CASES CONCERNING MULTINATIONAL ENTERPRISES}

Article 107(1) of TFEU establishes four conditions to rule on state aid. At first, there should be an "economic advantage". Secondly, this advantage should be provided by a Member State or via its resources. Thirdly, the aid should be selective. Finally, this aid should have the ability to distort competition and have an effect on trade between Member States. ${ }^{9}$

Since this Study mainly focuses on the selectivity criterion, the notion of "selectivity" should be elaborated. There is no prescribed definition of this concept in TFEU, therefore case-law has been an important tool to delineate the sphere of the notion. According to the case law, a selective measure grants advantages to specific undertakings or sectors over undertakings which are legally and factually in a similar situation.

In order to conclude that a tax advantage amounts to a selective aid, EU Courts formulated a separate three-step test. The first step is to sort out the "reference system". To qualify an aid as selective, "it is necessary to begin by identifying and examining the common or 'normal' regime applicable in the Member State concerned." 10 This identification is strictly relevant with the determination of the legally and factually comparable undertakings. The second step is to assess whether there is a derogation from that reference system. Accordingly, it is assessed whether the undertakings compared are subject to different treatments. ${ }^{11}$ Finally, the third step constitutes an assessment of whether the measure is "justified by the nature or general

9 Bacon, Kelyn (ed): European Union Law of State Aid, Oxford University Press, 2013, p.12.

10 Joined Cases C-78/08 \& C-80/08 Paint Graphos [2011] ECR I-7611

11 Joined Cases C-20/15 P \& C-21/15 P World Duty Free Group v Commission [2016] ECLI:EU:C:2016:981 $\$ 67$ 
scheme of the system of which [it] form [s] part". ${ }^{12}$ The burden of proof for a justification lies with the Member State.

This section will focus on the analysis of the Commission on the selectivity criterion regarding APAs. Within this scope, at first, we will explain the agenda of the Commission regarding taxation practices of MNEs. Secondly, we will analyze the findings of the Commission on the presumption of selectivity. Thereafter, we will focus on how the Commission applied three step test in case of APAs.

\section{A. Taxation Practices on MNEs}

APAs have been on the Commission's agenda since 2013, which dates back to before the Luxleak revelations. Within this scope, DirectorateGeneral for Competition ("DG Competition") initiated an inquiry, which specifically concentrated on APAs and proposed pricing methods of intragroup transactions endorsed in these agreements. ${ }^{13}$ In this sense, the Commission began to deliver decisions in late 2015.

On October 2015, the Commission found that Starbucks and Fiat benefitted from tax advantages respectively in Netherlands and Luxembourg. ${ }^{14}$ Within this scope, Commissioner Margrethe Vestager stated that "All companies, big or small, multinational or not, should pay their fair share of tax." In January 2016, the Commission concluded that a Belgian tax scheme results in illegal state aid. ${ }^{16}$ This decision concerned at least 35 MNEs. ${ }^{17}$ In August 2016, the Commission ruled on recovery of the aid Ireland granted to Apple through taxing rulings. ${ }^{18}$ In October 2017, the Commission concluded that illegal tax advantages were granted by

$12 \quad$ Paint Graphos v. Franchetto (n10) §64

13 Dg Competition, 'DG Competition Working Paper on State Aid and Tax Rulings' (2016) $<$ https://ec.europa.eu/competition/state_aid/legislation/working_paper_tax_ rulings.pdf $>$ accessed 3 April 2020

14 Respectively Starbucks/Netherlands (n6) and Fiat/Luxembourg (n6)

15 Commission, 'Commission decides selective tax advantages for Fiat in Luxembourg and Starbucks in Netherlands are illegal under EU state aid rules' (Brussels, press release, 2015)

16 Excess Profit exemption in Belgium

17 Commission, 'State aid: Commission concludes Belgian "Excess Profit" tax scheme illegal; around $€ 700$ million to be recovered from 35 multinational companies' (Brussels, press release, 2016)

18 Apple/Ireland 
Luxembourg to Amazon ${ }^{19}$ and on June 2018, once again by Luxembourg to Engie. $^{20}$

On September 2018, the Commission found that McDonalds did not benefit from selective advantages in Luxembourg. ${ }^{21}$ In December 2018, at the end of an inspection towards taxing rulings concluded by Gibraltar, five out of 165 taxing rulings were found to constitute state aid. ${ }^{22}$ And at last, United Kingdom tax scheme was scrutinized and some MNEs were found to be granted selective advantages. ${ }^{23}$ Besides the closed cases, there are ongoing investigations concerning taxing rulings granted by Netherlands to $\mathrm{Nike}^{24}$ and to $\mathrm{IKEA}^{25}$. A clear majority of these cases concern the misapplication or nonapplication of arm's length principle.

Unsurprisingly, these decisions have been challenged before the General Court. So far, General Court has approved the Luxembourg/Fiat decision. ${ }^{26}$ Thus, General Court approved the findings of the Commission on the grounds that standalones and MNEs are legally and factually comparable and the arm's length principle is appropriate for the purposes of this assessment. Even though the General Court annulled Starbucks/Netherlands decision, it contested how the arm's length principle was implemented in that concrete case, rather than the implementation of the principle itself. ${ }^{27}$ At last, General Court annulled the Apple/Ireland decision. Just like in the Starbucks/Netherlands case, the Court has made it clear that it backs the

19 Amazon/Luxembourg (Case 6740) Commission Decision SA.38944 (2014/C) (2014/NN) [2017] OJ L/153/2018

20 Engie/Luxembourg (Case 3839) Commission Decision SA.44888 (2016/C) (ex 2016/NN) [2018] OJ L/78/2019

21 McDonald's/Luxembourg (Case 6976) Commission Decision SA.38945 (2015/C) (ex 2015/NN) (ex 2014/CP) [2018] OJ L/195/2019

22 Gibraltar Corporate tax regime (Case 7848) Commission Decision SA.34914 (2013/C) [2018] OJ L/119/2019

23 State aid scheme UK CFC Group Financing Exemption (Case 2526) Commission Decision SA.44896 [2019] OJ L/216/2019

24 Commission, 'State aid: Commission opens in-depth investigation into tax treatment of Nike in the Netherlands' (Brussels, press release, 2019)

25 Commission, 'State aid: Commission opens in-depth investigation into the Netherlands' tax treatment of Inter IKEA' (Brussels, press release, 2017)

26 T-755/15 \& T-759/15 Luxembourg/Ireland/Fiat v. Commission [2019] ECLI:EU:T:2019:670

27 T-760/15 $\quad \S \quad$ T-636/16 Netherlands/Ireland/Starbucks $\quad v . \quad$ Commission [2019] ECLI:EU:T:2019:669 
implementation of the arm's length principle. ${ }^{28}$ The stance of ECJ is not known at the moment, since the Court has not delivered any decision.

\section{B. Presumption of Selectivity}

In the Commission's decisions concerning APAs, the Commission mentions that APAs are concluded individually and separately for each MNE. ${ }^{29}$ The Commission explains that when individual measures are at stake, the measure may be presumed to be selective. ${ }^{30}$ Since APAs are also individual measures, the Commission indicates that APAs are selective in nature. ${ }^{31}$ Therefore, if the contested APA amounts to an advantage, there is no need to prove the selectiveness of that agreement. ${ }^{32}$

In its appeal before the General Court, Fiat questioned the validity of this presumption. ${ }^{33}$ The General Court stated that the advantage and selectivity criteria are distinct from each other. Nevertheless, the General Court indicated that an aid scheme and an individual aid differ from each other when the selectivity criterion is assessed. The General Court asserted that in case of an individual measure, the presumption of selectivity rules. ${ }^{34}$ The Court put forward that presumption of selectivity necessities two conditions: the aid should be individual and an advantage should be valid. ${ }^{35}$ Within this scope, the Court firstly stated that Fiat would have paid more tax if the transfer prices were calculated in line with the arm's length principle. ${ }^{36}$ Therefore, an advantage was found to be valid in the concrete case.

Fiat and Luxembourg alleged that the aid in question was an implementation of a general rule and thus could not be counted as an individual aid. ${ }^{37}$ The General Court responded with three arguments. Firstly, the Court asserted that there was no provision in the national legislation to be

28 General Court of the European Union, 'The General Court of the European Union annuls the decision taken by the Commission regarding the Irish tax rulings in favour of Apple' (Luxembourg, press release, 2020) Netherlands/Starbucks §254; Amazon/Luxembourg §583; Apple/Ireland §224 Amazon/Luxembourg §583, 584; Apple/Ireland §224; Fiat/Luxembourg §218; Starbucks/Netherlands $\$ 254$

31 Apple/Ireland §224; Amazon/Luxembourg §584

32 Fiat/Luxembourg $\$ 218 ;$ Starbucks/Netherlands $\$ 254$

$33 \quad \mathrm{~T}-755 / 15 \& \mathrm{~T}-759 / 15 \$ 329$

34 ibid. $\$ 333$

35 ibid. $\$ 339$

36 ibid. $\$ 340$

37 ibid. $\$ 341$ 
counted as a scheme. ${ }^{38}$ Secondly, the measure in question was only directed to Fiat to calculate it's taxable profit. ${ }^{39}$ Thirdly, the tax authority had a margin of appreciation pursuant to the national legislation. According to the General Court, this margin of appreciation is the proof of an individual measure. ${ }^{40}$ Thus, the General Court has not found an error in the application of the presumption in case of APAs.

\section{First Step: Designation of The Reference System}

Although the Commission found APAs selective in nature, it applied the three step test in sake of completeness. ${ }^{41}$ Within the first step, the Commission has defined the reference system as the general corporate income tax system of the Member State concerned. ${ }^{42}$ The Commission highlights that the reference system of each state aims to impose taxes on every company on equal foot, whether it is a standalone or a group company. Therefore, the Commission acknowledges that MNEs are in the same box of cluster with standalones. The Commission thus sets the liability of MNEs, stating that MNEs are liable to pay tax on their "Member State concernedsourced" income.

The Commission also mentions that the calculation method of taxable profits of MNEs and standalones differ. However, the Commission states that this difference is only an artificial one. Accordingly, the taxable profit of a standalone is straightforward and its accounting profit is used to determine its taxes. In contrast, the taxable profit of a group company requires some estimation, since the profit of such undertakings rely on transfer prices rather than competitive prices in an open market. The Commission argues that this differentiation is only to "achieve the ultimate goal of determining the taxable base of both types of companies in a manner that ensures that integrated companies are taxed on an equal footing to non-integrated companies under the ordinary rules of taxation of corporate profit."43

Finally, the Commission states that even if the national legislation requires MNEs to be taxed in a different way, it would not change the

\footnotetext{
38 ibid. $\$ 350$

39 ibid. $\$ 351$

40 ibid. $\$ 352$

41 Amazon/Luxembourg §585; Apple/Ireland \$224.

42 For instance, in the Luxembourg/Fiat, the reference system is designated as "the general Luxembourg corporate income tax".

43 Apple/Ireland $\$ 230$
} 
result. ${ }^{44}$ In the Starbucks/Netherland decision, the Commission indicates that "the creation of a special regime that applies only to integrated companies, which deviates from the general Dutch corporate income tax rules, is in itself selective in nature, so that any benefit granted on the basis of that regime is selective in nature." 45 This "special regime" amounts to any regime which does not endorse the arm's length principle.

\section{Second Step: Derogation from The Reference System And Arm's Length Principle}

The Commission links its analysis on the "advantage" criterion with the second step of the three step test. Since the reference system includes all of the companies operating on that Member State, the Commission considers that if an advantage is granted to an MNE, that advantage also amounts to a derogation. ${ }^{46}$ When assessing the "advantage" criterion in some decisions, the Commission simply refers to the analysis on derogation. ${ }^{47}$ In the other decisions, the Commission analyses the advantage criterion and then makes a reference to that section when dealing with the derogation. ${ }^{48}$

In order to establish the derogation, the Commission relies on the arm's length principle. According to this principle, intra-group transfer prices should be estimated as if the transactions between intra-group companies are priced in an open market. In the Commission Notice, it is stated that "this arm's length principle necessarily forms part of the Commission's assessment granted to group companies under Article 107(1) of the Treaty, independently of whether a Member State has incorporated into its national legal system and in what form." 49

There seems to be three possible situations: a Member State enacts arm's length principle in its legislation, a Member State enacts the principle in its own interpretation into its legislation or the national legislation doesn't

\footnotetext{
$44 \quad$ Netherlands/Starbucks $\$ 250$

45 ibid. $\$ 250$

$46 \quad$ Netherlands/Starbucks $\$ 253$; Excess Profit exemption in Belgium $§ 131$

47 For instance in the Apple/Ireland case, when demonstrating that the tax ruling amounted to an advantage, the Commission has stated that "the Commission's assessment of whether the contested measures constitute a derogation from the reference system (the second step of the selectivity analysis) will coincide with its assessment of whether those measures confer an advantage on ASI and AOE"

48 Amazon/Luxembourg

49 Commission Notice on the Notion of State aid as referred to in Article 107(1) of the Treaty on the Functioning of the European Union 2016/C 262/01 [2016] OJ C $262 \$ 172$
} 
include such a principle. If the principle is endorsed in national legislation, the Commission could easily allege that a tax measure which is not in line with the principle endorsed in national legislation constitutes a derogation from the reference system.

Furthermore, the Commission does not approve the implementation of the arm's length principle as interpreted in the national legislation. In the Starbucks/Netherlands case before the Commission, Netherlands argued that instead of applying the provisions governing the arm's length principle in the national legislation, the Commission applied the principle according to its own interpretation. ${ }^{50}$ The Commission responded that its role is not to apply the national legislation but to apply article 107(1) of TFEU. ${ }^{51}$

Finally, in case that the arm's length principle is not a part of national legislation, the Commission nevertheless applies it to show the derogation. In the Apple/Ireland decision, Ireland argued that according to Irish tax law, taxes cannot be accrued pursuant to general principles. ${ }^{52}$ However, the Commission ascertained that the arm's length principle is a necessity within the perspective of Article 107(1) of TFEU and every Member State is obliged to comply with it. ${ }^{53}$

The Commission and the General Court put forward three grounds on implementation of the arm's length principle regardless of the national legislation. Firstly, it is claimed that "Where national tax law does not make a distinction between integrated undertakings and stand-alone undertakings for the purposes of their liability to corporate income tax, that law is intended to tax the profit arising from the economic activity of such an integrated undertaking as though it had arisen from transactions carried out at market prices." 54 Secondly, the Commission relies on the Belgium and Forum 187 v Commission judgement ${ }^{55}$ of the ECJ. ${ }^{56}$ To legitimize its stance, the Commission alleges that ECJ has already adopted the principle in its prior judgement. ${ }^{57}$ The Commission states that ECJ compared coordination

\footnotetext{
50 Netherlands/Starbucks $\$ 265$

51 ibid. $\$ 265$

52 Apple/Ireland $\$ 257$

53 ibid. $\$ 257$

$54 \mathrm{~T}-760 / 15 \S \mathrm{T}-636 / 16 \S 149$

55 Joined Cases C-182/03 and C-217/03 Belgium and Forum 187 v Commission [2006] ECR 2003 I-06887

56 Joris, Tony and De Couk, Wout p.697.

57 ibid. p. 613
} 
centers' taxable profit with the situations of free competition. For the reasons explained in the fourth section, we do not believe that ECJ has adopted the principle beforehand.

Thirdly, in the hearings before General Court -concerning Luxembourg/Fiat and Netherlands/Starbucks decisions- the Commission ascertained that the Member State adopted separate legal entity approach. According to the Commission, this approach concerns the taxation of legal entities rather than economic units and the arm's length principle is the concomitant principle of this approach. The Commission concludes that since this approach is adopted by the Member State, it is not important whether the national legislation enacts the arm's length principle. ${ }^{58}$ This line of reasoning was not accepted by the General Court, since the Commission did not mention it in its decisions and it cannot bring forward new arguments at that stage of the procedure. ${ }^{59}$ Nevertheless, in the Amazon/Luxembourg decision, the Commission has mentioned the separate legal entity approach as a basis to implement arm's length principle. ${ }^{60}$

\section{E. Third Step: Justification}

According to the third step of the test, if the different tax liabilities between comparable undertakings arise from "the nature and logic of the system", then the measure does not amount to illegal state aid. ${ }^{61}$ In most of the cases, Member States fail to justify the contested measures. ${ }^{62}$ In the Apple/Ireland case, Apple put forward that the discretion enjoyed by tax administrations is inherent to the tax system of Ireland and justifies the tax measure. ${ }^{63}$ However, the Commission argued that the discretion cannot justify different treatment to comparable undertakings. Furthermore, the Commission argued that a discretion that is not afforded with objective criteria gives rise to a presumption of selectivity and that Apple was unable to prove such objective criteria. ${ }^{64}$ Secondly, the Commission indicated that

\footnotetext{
$\mathrm{T}-755 / 15$ \& $\mathrm{T}-759 / 15 \S 152$

ibid. $\$ 153$

Amazon/Luxembourg §589

Engie/Luxembourg $\$ 227$

62 Amazon/Luxembourg §603; Apple/Ireland \$411; Engie/Luxembourg \$229; Fiat/Luxembourg §337; Starbucks/Netherlands §413.

Apple/Ireland $\$ 406$

ibid. $\$ 407$
} 
the selective advantage did not arise from the discretion enjoyed, but from the reduction of taxable profits. ${ }^{65}$

In some decisions, the Commission examined if the avoidance of double taxation could amount to a justification. ${ }^{66}$ In the Excess Profit exemption in Belgium case, the Commission agreed that avoidance of double taxation may be a justification. ${ }^{67}$ However, in this specific ruling, the Commission concluded that Belgium was unable to prove that the actual aim of the scheme was to avoid double taxation. Likewise, in Engie/Luxembourg case, avoidance of double taxation was put forward as a justification, which was not found admissible in concreto. ${ }^{68}$

It should also be noted that the third step both encompasses the derogation and the way the derogation is applied. ${ }^{69}$ In the Paint Graphos case, the aid in question was subject to a proportionality test. The measure in question was considered to be within the limits of what is necessary for the objective pursued..$^{70}$ Likewise, in the Heitkamp BauHolding case, it was held that if less far-reaching measures could achieve to the aim pursued, then the contested measure would not be justified. ${ }^{71}$

The Commission assessed the proportionality test to evaluate if the measure was proportionate to the aim of avoidance of double taxation in its decisions concerning MNEs. ${ }^{72}$ In the Engie/Luxembourg case the Commission underlined that while a Member State can exempt a tax to avoid double taxation, that Member State must also ensure that the exemption does not go beyond what is necessary. ${ }^{73}$ Accordingly, the Commission found that Engie benefited from double non-taxation and ruled that the measure was not proportionate. ${ }^{74}$ Likewise, in the Gibraltar Corporate Tax Regime case, the Commission ruled that "a full and automatic exemption measure is

\footnotetext{
65

ibid. $\$ 408$

66 Engie/Luxembourg §231; Excess Profit exemption in Belgium §172; Gibraltar Corporate tax regime $\$ 107$.

67 Excess Profit exemption in Belgium $\$ 172$

68 Engie/Luxembourg $\$ 231$

69 Cisotta, Roberto: Criterion of Selectivity in Hofmann Herwig C. H. and Micheau Claire (eds): State Aid Law of European Union, Oxford University Press, 2016, p.140.

$70 \quad$ Paint Graphos $\$ 75$

71 T-287/11 Heitkamp BauHolding GmbH v Commission [2016] ECLI:EU:T:2016:60 $\$ 160$

72 Gibraltar Corporate Tax Regime §107; Excess Profit exemption in Belgium §175; Engie/Luxembourg \$233.

73 Engie/Luxembourg $\$ 233$

74 ibid.
} 
disproportionate and the prevention of double taxation cannot be seen as an acceptable justification." 75

In sum, the Commission has presumed APAs selective due that these agreements are concluded individually with each MNE. Nevertheless, the Commission applied the three step test. The Commission designated the reference system as the general corporate income tax system of the Member States. Thereafter, the Commission implemented arm's length principle to the concrete tax measures to see if there is a derogation. Finally, the Commission put forward that avoidance of double taxation may be a justification for the contested tax measures, but the measure should also be proportionate for this aim.

\section{IS APA ITSELF A PROOF OF SELECTIVITY?}

As explained in the previous section, the Commission has evaluated that APAs are selective in nature. The General Court indicated that, in any event, APAs are individual measures due to the margin of appreciation enjoyed by tax authorities. Therefore, since an APA always comprises an appreciation of the parties ${ }^{76}$, the General Court excluded the possibility of an APA not to be presumed selective. We contest to the application of the presumption on two grounds.

Firstly, we argue that the implementation of such presumption causes the abolishment of a criterion in cases concerning MNEs and a different interpretation could have been made for the preservation of the selectivity criterion. This is firstly because, APAs are widespread, since these agreements provides security and predictability for the undertakings and the tax administrations ${ }^{77}$. Therefore, presuming APAs to be selective would amount to non-application of the selectivity criterion in nearly all cases concerning the taxation practices of MNEs.

Furthermore, without an APA, two possible scenarios would be at stake. In the first scenario, the Member State would apply a method to find the taxable profit of an MNE when it is time to procure tax. In this case, the measure -procurement of tax- would be very similar to an APA, apart from APAs being signed beforehand. Thus, the measure in the first scenario

75 Gibraltar Corporate Tax Regime $\$ 107$.

76 In the Fiat/Luxembourg $\$ 230$, the Commission assessed that "transfer pricing is not an exact science" and the arm's length principle has an "approximative nature".

77 APAs diminishes the possibility of legal disputes as well as the possibility to encounter double taxation. See Gonzalez, Saturnina Moreno, p.7. 
would also be regarded as an individual measure and presumed to be selective.

In the second scenario, the Member State would easily tax an MNE on its recorded profit. In this case, the presumption of selectivity would not be an issue, since taxation on recorded profit does not endorse margin of appreciation. However, in this situation, the Commission would immediately rule on illegal state aid, since the measure is not prima facie respecting the arm's length principle. As seen, while the only way to be on the safe side is to conclude APAs or tax measures that comply with arm's length principle, the existence of APAs or such tax measures leads to presumption of selectivity. This interpretation of the Commission and General Court is contrary to the prior assessments of ECJ in which it stated that advantage and selectivity are two distinct criteria under article 107(1) of TFEU. ${ }^{78}$

In order to implement the selectivity criterion, we believe that a different interpretation regarding the individuality of APAs is possible. We believe that the approximative nature of the arm's length principle -and therefore APAs- should not lead to presumption of selectivity. This is because, reaching an approximative outcome is still important for the Commission. ${ }^{79}$ The Commission constrains Member States on how to apply the principle. ${ }^{80}$ Accordingly a functional analysis of the MNE is constructed. Afterwards, "characteristics of the property or services; contractual terms; functions, assets and risks performed by the parties; economic conditions of the market; and any special circumstances such as business strategies" are checked to identify comparables. ${ }^{81}$ As seen, the Commission scrutinizes whether the contested APA is respecting a general rule. Therefore, we believe that APAs can be considered as an application of a general rule rather than an individual measure.

Secondly, we believe that the precedents of ECJ is contradictory with the findings of the Commission. In Commission v MOL case, ECJ assessed

\footnotetext{
78 C-15/14 P Commission v MOL [2015] ECLI:EU:C:2015:362 §59

79 Gonzalez, Saturnina Moreno, p.17.

80 ibid. p. 12

81 Eden, Lorraine: “The Arm's Length Standard: Making It Work in a 21st Century World of Multinationals and Nation States", Global Tax Justice, Oxford University Press $§ 12$ $<$ https://poseidon01.ssrn.com/delivery.php?ID=29606400308602202002911807500400 60230510840510440680220091030750271190270651171100250610011110550100011 21124028028019027099115126046036051078022065119065074002097055016028118 09500107906511210008811707206408911501100409311401908712707002911808109 5001\&EXT $=$ pdf $>$ accessed 21 December 2019
} 
whether the discretion of administrative authorities on the choice to conclude an extension agreement and the level of fee designated in that agreement was selective. $^{82}$ In this judgement, ECJ made a distinction between individual measures and general measures. ${ }^{83}$ However, ECJ added that the discretion of the administration was not sufficient to presume a measure as selective. The ECJ ruled that if the discretion is defined by law and is limited, that discretion cannot lead to presumption of selectivity. ${ }^{84}$ Furthermore, ECJ stated that a negotiation process in an agreement is not sufficient to rule on presumption of selectivity. ${ }^{85}$

On the contrary, the Commission in its decisions regarding MNEs implements presumption of selectivity, since these agreements are directed to one undertaking and margin of appreciation is enjoyed during the procedure. We believe that ECJ has a narrower perception regarding presumption of selectivity and the findings of ECJ contradicts the assessments of the Commission.

To sum, we contested to the application of presumption of selectivity on two grounds. Firstly, we argued that this presumption causes the abolishment of a criterion in cases concerning MNEs. Therefore, for the sake of a complete assessment, the interpretation regarding individuality of APAs may be altered. For this purpose, we believe that the Commission can consider these agreements as an application of a general rule, rather than an individual measure. Secondly, we believe that the case law of ECJ is contradictory with the Commission's findings on presumption of selectivity.

\section{ARE STANDALONES AND MULTINATIONALS IN A LEGALLY AND FACTUALLY COMPARABLE SITUATION?}

The Commission, in the decisions regarding MNEs, designated the reference system in the broadest manner possible as the corporate tax system and found MNEs and standalones legally and factually comparable. Thus, the advantage and selectivity criterion overlapped, since advantage is by definition any measure granted to an undertaking or several undertakings unlike the others. ${ }^{86}$

\footnotetext{
$82 \quad$ ibid. $\$ 49$

83 ibid. $\$ 60$

84 ibid. $\$ 64$

85 ibid. $\$ 66$

86 Lopez, Hugo Lopez: "General Thought on Selectivity and Consequences of a Broad Concept of State Aid in Tax Matters" European State Aid Law Quarterly, 9, 4, 2010,
} 
In this section we will argue that MNEs are not in a comparable situation with standalones. For this purpose, we will submit two main arguments. At first, we will argue that tax competition between Member States makes a distinction between MNEs and standalones. Secondly, we will discuss that the differences between intra-group transactions and open market transactions make a further distinction between MNEs and standalones.

\section{A. Tax Competition Among the States}

MNEs have the ability to allocate their revenues in states of their own choices. Since transfer prices are set by the group company, an MNE has a wide discretion in this regard. ${ }^{87}$ Furthermore, freedom of establishment provides mobility for undertakings. ${ }^{88}$ Accordingly, Article 49 of TFEU guarantees to an undertaking operating in one Member State to "carry out an economic activity in a stable and continuous way in another Member State. $"{ }^{\circ 9}$ Thus, the headquarter of a group company may establish a subsidiary in a state by considering the pros and cons of those states. Surely, liability to tax is one of these pros and cons to consider.

On the other side of the equation, states desire to attract foreign investment. States proposing low taxes gain a competitive advantage over states proposing higher taxes. ${ }^{90}$ An MNE offers benefits such as foreign investment, employment, more taxes in total compared to a standalone. Thus, tax competition among states are observed in sake of the real benefits attached to it.

The existence of such a competition is also explicit in the decisions of the Commission. In the Excess Profit exemption in Belgium decision, the

p.809 <https://0-www-jstor-org.libunix.ku.edu.tr/stable/pdf/26686105.pdf?ab_segments $=0 \% 252 \mathrm{Fbasic}$ search $\% 252 \mathrm{Fcontrol \& refreqid}=$ excelsior\%3Aa27a4af4ed1a748a09bfbd 1b353ce141> accessed 22 May 2020

87 Giraud, Adrien and Petit, Sylvain Petit: "Tax Rulings and State Aid Qualification: Should Reality Matter?", European State Aid Law Quarterly, 16, 2, 2017, p.236 $<$ https://www.jstor.org/stable/26694140?seq=1\#metadata_info_tab_contents $>$ accessed 21 December 2019

88 European Parliament, 'Freedom of Establishment and Freedom To Provide Services' (Strasburg, Fact Sheet, 2020)

89 ibid.

90 Valente, Piergiorgio: "Competitive Taxation and Tax Competition: The Winner Takes It All?" Kluwer International Tax Blog <http://kluwertaxblog.com/2019/03/04/ competitive-taxation-and-tax-competition-the-winner-takes-it-all/?doing_wp_cron= 1590663125.2385098934173583984375> accessed 28 May 2020 
advantage was only granted when an MNE relocated its revenue or enhanced its activities in the Belgian jurisdiction. ${ }^{91}$ Furthermore, the contested aid scheme was introduced with the slogan "Only in Belgium". ${ }^{92}$ A second example can be found in the Apple/Ireland decision. ${ }^{93}$ In this decision the Commission stated that one of the contested rulings was the outcome of a negotiation process. ${ }^{94}$

Giraud and Petit argue that the Commission has not considered the counterfactual scenario. ${ }^{95}$ The authors are of the view that if an MNE is not provided with a satisfactory tax ruling, then this MNE would locate its profit in another territory with better benefits. ${ }^{96}$ Thus, absent a favorable tax ruling, there may have been no revenue to tax to begin with.

It could be argued that the Commission does not approve tax competition and therefore would not consider it to make a distinction between MNEs and standalones. Indeed, some scholars argue that the Commission seems to target tax competition by interrupting in the fiscal areas of the Member States ${ }^{97}$ and aims a harmonization of tax rules. However, such a harmony at the EU level does not exist at the time being. Unless this harmonization is established regarding the taxation practices on MNEs, state aid law cannot be used for such purpose. ${ }^{98}$ Indeed in the Groepsrentebox Scheme case, the Commission underlined that "Corporate tax rates are not harmonized in the EU, and the Netherlands are not in control of the rates applied by other countries. If undertakings manage to take advantage of the difference in tax rates, i.e. of the lack of

$91 \quad$ Excess Profit exemption in Belgium $\$ 21$

92 ibid. $\$ 42$

93 Giraud, Adrien and Petit, Sylvain, p.236.

94 Apple/Ireland $\$ 147$

95 Giraud, Adrien and Petit, Sylvain, p.236.

96 ibid. p.236

97 Verhagen, Han: "State Aid and Tax Rulings - An Assessment of the Selectivity Criterion of Article 107(1) of the TFEU in Relation to Recent Commission Transfer Pricing Decisions", European Taxation, 2017, p.279 <https://www.ibfd.org/sites/ ibfd.org/files/content/pdf/et_2017_07_int_1_PPV_AugNewsletter.pdf $>$ accessed 10 December 2019

98 Gormsen, Liza Lovdahl: "EU State Aid Law and Transfer Pricing: A Critical Introduction to a New Saga" $2016<\mathrm{https} / /$ www.law.ox.ac.uk/business-law-blog/blog/ 2016/09/eu-state-aid-law-and-transfer-pricing-critical-introduction-new-saga $>$ accessed 22 May 2020 
harmonization, the Netherlands is not responsible."99 As seen, state aid law aims to control the internal harmony of national legislations, rather than the harmonization of the tax rules at the EU level. ${ }^{100}$ Furthermore, selectivity criterion should be related to whether or not a policy or fact differentiates two types of undertakings, rather than approval of it. Therefore, we believe that tax competition is sufficient to show the difference between MNEs and standalones.

Finally, negotiation power is also taken into consideration by the ECJ in the MOL v. Commission. ${ }^{101}$ The ECJ stated that "the fact that the rates set by year of validity of the 2005 agreement are the result of negotiation does not suffice to confer on that agreement a selective character, and that the situation would have been different only if the Hungarian authorities had exercised their margin of assessment in such a way as to favour MOL by agreeing to a low fee level without any objective reason having regard to the rationale of increasing fees in the event of an extension of authorization and to the detriment of any other operator having sought to extend its mining rights or, if there is no such operator, where there is concrete evidence that unjustified favourable treatment has been reserved to MOL."102 Since the mobility of MNEs offer them a negotiation power and this power generates competition between states, tax competition and negotiation power should be considered when designating the reference system.

\section{B. Differences Between Intra-Group Transactions and Open Market Transactions}

The Commission, by implementing the arm's length principle, assumes intra-group transactions and open market transactions to be of same nature. However, these transactions differ from a variety of features. We believe that these reasons are sufficient to conclude that MNEs and standalones are not factually comparable on two grounds.

At first, we believe that if a group company would have the same commercial benefits without getting integrated, then this company would not have established subsidiaries. Nicolaides states that "if the Commission considers that group companies are the same as independent companies, it

\footnotetext{
99 Groepsrentebox Scheme (Case 4511) Commission Decision C4/2007 (ex N 465/2006) [2009] OJ L/288/2009 §40

100 For the same conclusion see Gonzalez, Saturnina Moreno, p.21.

101 Commission v MOL

102 ibid. $\$ 66$
} 
will have to come up with a credible explanation why group companies exist in the first place. Why do companies bother to set up subsidiaries if they can obtain the same benefits from arm 's length transactions?"103

Eden presents some reasons as to why theoretically there are no comparables to reach the arm's length price of intra-group transactions. ${ }^{104}$ We believe that these reasons also show why group companies exist in the first place and why the intra-group and open market transactions differ. According to Eden company transactions do not endure ex ante and ex post market-making costs. For instance, ex ante costs such as search, negotiation and monitoring costs and ex post costs such as dispute settlement costs are not applicable to intra-group transactions. ${ }^{105}$ These costs are also an indicator of the risk element that independent parties have to bear. Associated transacting parties have knowledge of each other's capacity and accountability. ${ }^{106}$ Therefore, we believe that the Commission should have considered the difference on costs and risks endured by associated parties when designating the reference system.

Secondly, the intra-group transactions and open market transactions differ from the perspective of their aims on the generation of profit. When a standalone makes a transaction with another undertaking, this undertaking aims to maximize its own revenue. However, in case of intra-group transactions the aim would not be to increase each entities' revenues but the group's revenue itself. ${ }^{107}$ For one thing, group companies intent to avoid double marginalization. When an associated party sell a product at cost to the other associated party and when they sell the product to the customers at the highest price, the combined profits gets higher compared to the situations in open market transactions. ${ }^{108}$

In fact, the Commission agreed that this aim factor makes a distinction between standalones and group companies in its prior decisions. In the Hungarian tax deductions for intra-group interest case, the Commission assessed an aid scheme which exempted half the amount of net interest

\footnotetext{
103 Nicolaides, Phedon, p.423.

104 Eden, Lorraine, p.15.

105 ibid. p. 15
}

106 Nicolaides, Phedon, p.423 also emphasizes the importance of the risk element and compares MNEs and standalones in this regard.

107 Eden, Lorraine, p.15.

108 Nicolaides, Phedon, p.422. 
obtained from associated companies. ${ }^{109}$ The Commission concluded that group companies and standalones are not comparable on debt financing activities. The Commission stated that "related companies are not engaged in a merely commercial transaction, unlike unrelated companies, when they try to obtain loan or equity financing within the group. The parent and the subsidiary share the same interests, which is not the case of a commercial transaction with a third-party provider of finance, where each party tries to maximise its profits at the expense of the other." ${ }^{110}$ Since standalones try to maximize their own revenue and engage in commercial transactions, but group companies try to maximize their combined revenue and share the same interest, the same line of reasoning should also be valid in case of taxation practices of MNEs. ${ }^{111}$

Unsurprisingly, Member States and MNEs also claimed that the Commission has recognized group effect in its prior decisions. ${ }^{12}$ However, the Commission alleged that this interpretation would be a misreading of the prior decision. ${ }^{113}$ According to the Commission, the objective of exemption of arbitrage is distinct from the determination of taxable profits of a group company. ${ }^{114}$ The Commission alleged that exemption of arbitrage would primarily originate in group companies ${ }^{115}$ unlike calculation of taxable profit which is valid for every company. ${ }^{116}$

It is true that in the Hungarian tax deductions for intra-group interest case, the specific issue was financing of associated parties which is unavailable to unassociated parties. However, unassociated parties could also be financed through financial institutions and the net interest through financing is also borne on their account. Likewise, in the cases regarding MNEs, the Commission specifically scrutinizes the calculation of transfer prices, which is only available in the group context. Furthermore, the Commission in the Hungarian tax deductions for intra-group interest case focuses on the difference of transactions, rather than the availability of them to unassociated parties. The Commission highlights that independent parties

\footnotetext{
109 Hungarian tax deductions for intra-group interest (Case 8130) Commission Decision C 10/07 (ex NN 13/07) [2009] OJ L/42/3 §8

110 ibid. $\$ 111$

111 Verhagen, Han, p.283.

112 Fiat/Luxembourg $\$ 201$

113 Fiat/Luxembourg §313; State aid scheme UK CFC Group Financing Exemption $\$ 142$.

114 Fiat/Luxembourg $\$ 208$

115 Fiat/Luxembourg $\$ 203$

116 ibid. $\$ 208$
} 
get into commercial transactions while group companies have the same interests.

The Commission also alleges that in the Hungarian tax deductions for intra-group interest case, it has evaluated the reference system at the individual entity level rather than at the group level. ${ }^{117} \mathrm{We}$ believe that this interpretation is also misleading, since the Commission assessed the aid at the individual entity level and nevertheless mentioned the group effect and concluded that standalones and group companies are not comparable.

In the Groepsretebox Scheme case, the aid also concerned the financing of group companies. ${ }^{118}$ In that case, one more consequence of being a group company was examined. Since only financial institutions grant loan to standalone firms, the Commission compared financial institutions with the group companies. The Commission concluded that the financing activities are the main profits of financial institutions. However, financing of an associated party does not generate any profit at the group level. ${ }^{119}$ Likewise, in case of MNEs, while the transactions between standalones are their main sources of revenue, intra-group transactions do not generate profits at the group level. Therefore we believe that the reasoning in the Groepsretebox Scheme should also be valid for MNEs.

In sum, we argued that standalones and MNEs are not legally and factually comparable. At first, we discussed that tax competition between Member States draw a distinction between these undertakings. Secondly, we argued that the intra-group transactions and open market transactions differ from each other. The risks and costs applicable to open market transactions are not valid for intra-group transactions. Furthermore, while the ultimate goal of a standalone in a transaction is to maximize the profit, the group companies share the same interest. We believe that these factors differentiate MNEs and standalones factually and legally.

\section{IS THE LEGAL BASIS FOR IMPLEMENTATION OF ARM'S LENGTH PRINCIPLE LEGITIMATE?}

The Commission has stated that the arm's length principle is a necessity for the application of article 107(1) of TFEU regardless of the national

\footnotetext{
117 ibid. $\$ 313$

118 Groepsrentebox Scheme $§ 11$

119 ibid. $\$ 91$
} 
legislation. $^{120}$ The Commission relied on Belgium and Forum $187 v$ Commission judgement and inserted that ECJ has adopted arm's length principle. However, after a closer look at the judgement, we disagree with the Commission. $^{121}$

In the relevant decision, ECJ assessed a tax regime applied to coordination centers which belonged to an MNE and satisfied some other conditions. $^{122}$ In the decision, ECJ referenced to the cost-plus method and concluded that the advantage may be established by "compar[ing] that regime with the ordinary tax system, based on the difference between profits and outgoings of an undertaking carrying on its activities in conditions of free competition." "123 The ECJ indeed assessed whether the intra-group transactions were taxed as if they were open market transactions.

However, we should also question the content of "ordinary tax system" which the ECJ compared with the contested tax regime. In the case before the ECJ, the Belgian legislation has incorporated cost-plus method of OECD. ${ }^{124}$ In fact, in the contested Commission decision, the Commission stated that "Where -as is the case in Belgium- this comparable base is subject to the normal rate of corporation tax, the ultimate objective of establishing a comparable amount of tax has been achieved, and the application of the cost-plus method confers no advantages. The Commission's view is that the cost-plus method used by Belgium as part of the scheme covering the centres does not guarantee that income from free competition is taken into account; still less does it guarantee taxation comparable with that applied to other companies subject to the ordinary tax system." 125 Thus the Commission in the Aid scheme implemented by Belgium for coordination centres case designated the reference system as was laid down in the Belgian legislation. It would only be an assumption to state that the Commission and ECJ would still implement arm's length principle if

120 Fiat/Luxembourg §228; Apple/Ireland §249; Starbucks/Netherlands §260-262; Excess Profit exemption in Belgium $\$ 147$

121 See for the same conclusion: Verhagen, Han, p.285.

122 Belgium and Forum $187 v$ Commission

123 ibid. $\$ 95$

124 See Verhagen, Han, p.285; Joris, Tony and De Couk, Wout, p.614; Gonzalez, Saturnina Moreno, p.20.

125 Aid scheme implemented by Belgium for coordination centres established in Belgium (Case 564) Commission Decision 2003/757/EC [2003] 
those were not laid down in the legislation. ${ }^{126}$ We believe that this judgement may only be used as a precedent where a national legislation authorizes the principle.

Moreover, in this judgement, the ECJ stated that the selective nature of the tax regime arose from the fact that the regime was only applicable for some MNEs. ${ }^{127}$ In other words, ECJ did not compare MNEs with standalones. ${ }^{128}$ This fact alone demonstrates that this judgement of the ECJ is not in line with the Commission's decisions regarding MNEs. In sum, we believe that Belgium and Forum 187 v Commission judgement may not be a proper legal basis for the Commission Rulings ${ }^{129}$ since the Commission doesn't investigate national legislation and directly apply the arm's length principle to the concrete case in its decisions regarding MNEs.

\section{CONCLUSION}

Throughout the study, we questioned the analysis of the Commission on the selectivity criterion in the decisions regarding MNEs. For this purpose, in the second section, we examined the Commission's findings on presumption of selectivity in case of APAs. We concluded that presuming APAs would amount to the abolishment of selectivity criterion. We argued that applying arm's length principle may be considered as the application of a general rule and therefore APAs may not be considered as an individual measure. Afterwards, we reviewed the prior case law and concluded that the Commission decisions regarding MNEs is not in line with the precedents.

Secondly, we argued that MNEs and standalones are not factually and legally comparable. Within this scope, we argued that the notion of negotiation or discretion of administrative authorities is not an excluded practice in state aid law. Since the tax competition between Member States provides a negotiation power to MNEs, we concluded that this competition makes a distinction between MNEs and standalones. Secondly, we examined that intra-group transactions and open market transactions are not alike. Unlike transactions between independent parties, transactions between associated parties do not involve market making costs and the risks regarding the uncertainty intrinsic to the reciprocal obscurity of both parties.

\footnotetext{
126 Joris, Tony and De Couk, Wout, p.614.

127 Belgium and Forum $187 v$ Commission $\$ 122$

128 Gonzalez, Saturnina Moreno, p.20.

129 Verhagen, Han, p.285.
} 
Furthermore, we argued that the aims of intra-group and open market transactions differ.

Finally, we questioned the legal basis of the Commission on the application of arm's length principle. We came into a conclusion that the Commission would only base to the precedents where the national legislation incorporates arm's length principle. Therefore, we believe that state aid law may not be an appropriate tool for achieving the goals of the Commission on taxation practices of MNEs. ${ }^{130}$

130 For the same conclusion see Giraud, Adrien and Petit, Sylvain, p.234. 


\section{BIBLIOGRAPHY}

\section{Books and Articles}

Bacon, Kelyn (ed): European Union Law of State Aid, Oxford University Press, 2013.

Cisotta, Roberto: Criterion of Selectivity in Hofmann Herwig C. H. and Micheau Claire (eds): State Aid Law of European Union, Oxford University Press, 2016

Eden, Lorraine: “The Arm's Length Standard: Making It Work in a 21st Century World of Multinationals and Nation States", Global Tax Justice, Oxford University Press <https://poseidon01.ssrn.com/ delivery.php?ID=2960640030860220200291180750040060230510840 510440680220091030750271190270651171100250610011110550100 011211240280280190270991151260460360510780220651190650740 020970550160281180950010790651121000881170720640891150110 $04093114019087127070029118081095001 \& E X T=$ pdf $>$ accessed 21 December 2019

Giraud, Adrien and Petit, Sylvain Petit: "Tax Rulings and State Aid Qualification: Should Reality Matter?", European State Aid Law Quarterly, 16, 2, 2017, <https://www.jstor.org/stable/26694140?seq= 1\#metadata_info_tab_contents> accessed 21 December 2019

Gonzalez, Saturnina Moreno: "State aid, tax competition and BEPS: comments on the European Commission's decisions on transfer pricing rulings" University of Leicester School of Law Research Paper, 17, $2017<$ https://poseidon01.ssrn.com/delivery.php?ID=00712307201309 811300312509711812606902907307201408306602708307009208201 309209310702404304201305803802604507502810100609609710200 601602300106006709306410901809302211302305907809011007812 700307802411808206506602601903011510208307600007007000300 0025082090\&EXT $=$ pdf $>$ accessed 3 May 2020

Gormsen, Liza Lovdahl: "EU State Aid Law and Transfer Pricing: A Critical Introduction to a New Saga" $2016<$ https://www.law.ox.ac.uk/ business-law-blog/blog/2016/09/eu-state-aid-law-and-transfer-pricingcritical-introduction-new-saga $>$ accessed 22 May 2020

Joris, Tony and De Couk, Wout: "Is Belgium and Forum 187 v. Commission a Suitable Legal Source for an EU "At Arm's Length Principle"' European State Aid Law Quarterly, 16, 4, 2017 
$<$ https://www.jstor.org/stable/26694193?seq=1\#metadata_info_tab_con tents $>$ accessed 10 December 2019

Lopez, Hugo Lopez: "General Thought on Selectivity and Consequences of a Broad Concept of State Aid in Tax Matters" European State Aid Law Quarterly, 9, 4, 2010, <https://0-www-jstor-org.libunix.ku.edu.tr/stable/ $\mathrm{pdf} / 26686105$.pdf?ab_segments $=0 \% 252 \mathrm{Fbasic}$ _search $\% 252 \mathrm{Fcontrol \& r}$ efreqid $=$ excelsior\%3Aa27a4af4ed1a748a09bfbd1b353ce141> accessed 22 May 2020

Nicolaides, Phedon: "State Aid and Tax Rulings", European State Aid Law Quarterly, 15, 3, 2016, <https://www.jstor.org/stable/26694075?seq= 1\#metadata_info_tab_contents $>$ accessed 17 April 2020

Valente, Piergiorgio: "Competitive Taxation and Tax Competition: The Winner Takes It All?" Kluwer International Tax Blog $<$ http://kluwertaxblog.com/2019/03/04/competitive-taxation-and-taxcompetition-the-winner-takes-it-all/?doing_wp_cron $=1590663125.238$ 5098934173583984375 $>$ accessed 28 May 2020

Verhagen, Han: "State Aid and Tax Rulings - An Assessment of the Selectivity Criterion of Article 107(1) of the TFEU in Relation to Recent Commission Transfer Pricing Decisions", European Taxation, 2017, <https://www.ibfd.org/sites/ibfd.org/files/content/pdf/et_2017_ 07_int_1_PPV_AugNewsletter.pdf $>$ accessed 10 December 2019

\section{Notices and Policy Papers}

Commission, 'State aid: Commission opens in-depth investigation into tax treatment of Nike in the Netherlands' (Brussels, press release, 2019)

Commission, 'State aid: Commission opens in-depth investigation into the Netherlands' tax treatment of Inter IKEA' (Brussels, press release, 2017)

DG Competition, 'DG Competition Working Paper on State Aid and Tax Rulings' (2016) <https://ec.europa.eu/competition/state_aid/legislation/ working_paper_tax_rulings.pdf $>$ accessed 3 April 2020

European Parliament, 'Freedom of Establishment and Freedom To Provide Services' (Strasburg, Fact Sheet, 2020)

European Commission, 'Commission Staff Working Document Accompanying the Document Report from The Commission to the European Parliament, The Council, The European Economic and Social Committee and The Committee of the Regions Report on Competition 
Policy 2018' (2019) <https://ec.europa.eu/competition/publications/ annual_report/2018/part2_en.pdf $>$ accessed 3 March 2020

General Court of the European Union, 'The General Court of the European Union annuls the decision taken by the Commission regarding the Irish tax rulings in favour of Apple' (Luxembourg, press release, 2020)

OECD, 'OECD Transfer Pricing Guidelines for Multinational Enterprises and Tax Administrations 2017' (2017) OECD Publishing $<$ https://read.oecd-ilibrary.org/taxation/oecd-transfer-pricingguidelines-for-multinational-enterprises-and-tax-administrations2017_tpg-2017-en\#page5> accessed 14 April 2020

U.S. Department of the Treasury, The European Commission's Recent State Aid Investigation of Transfer Pricing Rulings (White Paper, 2016)

\section{Cases}

Aid scheme implemented by Belgium for coordination centres established in Belgium (Case 564) Commission Decision 2003/757/EC [2003]

Amazon/Luxembourg (Case 6740) Commission Decision SA.38944 (2014/C) (2014/NN) [2017] OJ L/153/2018

Apple/Ireland (Case 5605) Commission Decision SA.38373 (2014/C) (ex 2014/NN) (ex 014/CP) [2016] OJ L/187/2017

C-15/14 P Commission v MOL Magyar [2015] ECLI:EU:C:2015:362

Engie/Luxembourg (Case 3839) Commission Decision SA.44888 (2016/C) (ex 2016/NN) [2018] OJ L/78/2019

Excess Profit exemption in Belgium (Case 9837) Commission Decision SA.37667 (2015/C) (ex 2015/NN) [2015] OJ L/260/2016

Gibraltar Corporate tax regime (Case 7848) Commission Decision SA.34914 (2013/C) [2018] OJ L/119/2019

Groepsrentebox Scheme (Case 4511) Commission Decision C4/2007 (ex N 465/2006) [2009] OJ L/288/2009

Hungarian tax deductions for intra-group interest (Case 8130) Commission Decision C 10/07 (ex NN 13/07) [2009] OJ L/42/3

Fiat/Luxembourg (Case 7152) Commission Decision SA.38375 (2014/C ex 2014/NN) [2015] OJ L/351/2016

Joined Cases C-182/03 and C-217/03 Belgium and Forum 187 v Commission [2006] ECR 2003 I-06887 
Joined Cases C-20/15 P \& C-21/15 P World Duty Free Group v Commission [2016] ECLI:EU:C:2016:981

Joined Cases C-78/08 \& C-80/08 Paint Graphos v. Franchetto [2011] ECR I-7611

Joined Cases T-755/15 and T-759/15 Luxembourg/Ireland/Fiat $v$. Commission [2019] ECLI:EU:T:2019:670

Joined Cases T-760/15 and T-636/16 Netherlands/Ireland/Starbucks $v$. Commission [2019] ECLI:EU:T:2019:669

McDonald's/Luxembourg (Case 6976) Commission Decision SA.38945 (2015/C) (ex 2015/NN) (ex 2014/CP) [2018] OJ L/195/2019

State aid scheme UK CFC Group Financing Exemption (Case 2526) Commission Decision SA.44896 [2019] OJ L/216/2019

Starbucks/Netherlands (Case 7143) Commission Decision SA.38374 (2014/C ex 2014/NN) [2015] OJ L/83/2017

T-287/11 Heitkamp BauHolding GmbH v Commission [2016] ECLI:EU:T:2016:60 